Gut, 1973, 14, 270-274

\title{
Inhibition of the lower oesophageal sphincter by fat- a mechanism for fatty food intolerance
}

\author{
OTTO T. NEBEL ${ }^{1}$ AND DONALD O. CASTELL ${ }^{2}$ \\ From the Gastrointestinal Branch, Internal Medicine Service, Naval Hospital, Philadelphia, Pennsylvania
}

SUMMARY The effect of fat and protein meals on the lower oesophageal sphincter pressure was tested in normal subjects using an infused open-tipped manometric system. After ingestion of a minced beef meal, the mean peak pressure at the lower oesophageal sphincter increased $5.8 \pm 1.5$ $\mathrm{mm} \mathrm{Hg}( \pm 1 \mathrm{SE})$. By contrast, ingestion of a corn oil meal resulted in a mean peak decrease of $7 \cdot 8 \pm$ $1.9 \mathrm{~mm} \mathrm{Hg}$. Following the combined minced beef/corn oil meal, mean peak pressure decreased $3.0 \pm 2 \cdot 1 \mathrm{~mm} \mathrm{Hg}$. Pentagastrin $(3 \mu \mathrm{g} / \mathrm{kg}$, subcutaneously) resulted in a mean peak increase of $20.6 \pm$ $7.0 \mathrm{~mm} \mathrm{Hg}$ when given to the subjects in the fasting state, and produced an increase of only $8.4 \pm 1.7$ $\mathrm{mm} \mathrm{Hg}$ when given following the fat meal. Finally, after a mean peak decrease in pressure at the lower oesophageal sphincter of $6.8 \pm 1.0 \mathrm{~mm} \mathrm{Hg} 15$ minutes after the corn oil meal, gastric alkalinization with $30 \mathrm{ml}$ of antacid resulted in a subsequent increase in sphincter pressure of $5.2 \pm 1.6 \mathrm{~mm}$ $\mathrm{Hg}$. These data indicate: (1) Fat attenuates the effect of endogenous gastrin as well as exogenous pentagastrin stimulation of the lower oesophageal sphincter. (2) Fat-induced incompetency of the lower oesophageal sphincter can be effectively combated by gastric alkalinization in the form of antacids.

Symptomatic gastroesophageal reflux secondary to incompetence of the lower oesophageal sphincter is a common clinical problem. This symptom often occurs after eating, yet little is known about changes in the strength of the lower oesophageal sphincter after food. Recent studies utilizing relatively pure foods have shown that protein ingestion causes significant increases in sphincter pressure, and carbohydrate produces only slight increases in pressure. By contrast, the ingestion of a fat meal results in prompt and sustained decreases in pressure in this sphincter (Nebel and Castell, 1972).

The purpose of the present study was to determine the relative effects of protein and fat meals on lower oesophageal sphincter pressure, and to investigate the mechanism of fat-induced inhibition of sphincter pressure.

\footnotetext{
${ }^{1}$ Present address: Naval Hospital, San Diego, California

'Please send reprint requests and all correspondence to Naval Hospital, Philadelphia, Pennsylvania 19145 (Dr Castell)

Received for publication 11 January 1973.
}

\section{Methods and Materials}

INTRALUMINAL PRESSURE MEASUREMENT Three water-filled polyvinyl tubes $1.4 \mathrm{~mm}$ in internal diameter transmitted intraluminal pressure to external transducers (Statham Series p 23), and the pressure was recorded on a multi-channel direct-writing recorder (Hewlett Packard 7700 series) in millimetres of mercury with the mean gastric fundic pressure being used as the zero reference. The tubes were constructed so that intraluminal pressures were recorded through three lateral openings $1.5 \mathrm{~mm}$ in diameter placed $5 \mathrm{~cm}$ apart beginning $10 \mathrm{~cm}$ from the tip. With the subject supine, the tube was passed into the stomach and slowly withdrawn until it was positioned so that the distal aperture recorded fundic pressure, the middle aperture lower oesophageal sphincter pressure, and the proximal aperture the oesophageal pressure. Belt pneumographs around the chest and throat allowed monitoring of the respirations and swallowing. The tube used to record lower oesophageal sphincter pressure was infused with distilled water at a constant rate of $0.42 \mathrm{ml} / \mathrm{min}$. To ensure that the tube remained properly positioned 
in the sphincter throughout the study, the middle aperture was moved distally and slowly withdrawn across the sphincter at 10 -minute intervals. Studies were performed on 10 healthy male volunteer subjects between the ages of 19 and 34 (mean $=21$ years).

\section{TEST MEALS}

Test meals consisted of 150 calorie quantities of protein or fat in a total volume of $150 \mathrm{ml}$. In previous studies, equicaloric meals have been used to test their effect on both gastric secretion (Saint-Hilaire, Lavers, Kenneely, and Code, 1960) and the lower oesophageal sphincter (Nebel and Castell, 1972). The protein meal contained $50 \mathrm{~g}$ of cooked minced beef with $120 \mathrm{ml}$ of water. Corn oil (Lipomul), $25 \mathrm{ml}$ with $125 \mathrm{ml}$ of water, was used as the fat meal. The combined protein and fat meal (300 calories) consisted of cooked minced beef $(50 \mathrm{~g})$, Lipomul $(25 \mathrm{ml})$, and water $(100 \mathrm{ml})$. Each of the three meals was eaten by five normal subjects on separate days following a 20-minute basal period. Pressure was recorded for 60 minutes after the meal.

\section{PENTAGASTRIN AND FAT}

The effect of exogenous pentagastrin ${ }^{1}(3 \mu \mathrm{g} / \mathrm{kg}$, subcunateously) both in the fasting state and following a fat meal was also tested. In the initial studies lower oesophageal sphincter pressure was monitored for a 20-minute basal period and for 20 minutes after pentagastrin injections in five normal subjects. On

'Supplied as AY-6608 (Pentavlon) by Ayerst Laboratories, New York, New York. the following day each of the subjects ingested the 150 calorie fat meal following the basal period. Fifteen minutes after the meal, pentagastrin was given and the recording continued for another 20 minutes.

\section{GASTRIC ALKALINIZATION AND FAT}

Lower oesophageal sphincter pressure was monitored for a 20-minute basal period and for 15 minutes after corn oil ingestion (150 calories) in five normal subjects. Each subject then swallowed $30 \mathrm{ml}$ of a commercial antacid and pressure was measured for an additional twenty minutes.

\section{ANALYSIS OF DATA}

Lower oesophageal sphincter pressure for each minute of the test was read directly from the recording. Basal pressure represented the mean value for 20 such determinations. After administration of the test substances a mean pressure for each five successive one-minute periods was calculated and used for presentation of the data. Student's $t$ test for paired samples was utilized for evaluating statistical significance between mean pressure levels.

\section{Results}

\section{PROTEIN AND FAT INGESTION}

After the ingestion of the protein meal, lower oesophageal sphincter pressure consistently increased in all five subjects. The peak rise in pressure of $5.8 \pm$ $1.5 \mathrm{~mm} \mathrm{Hg}$ (mean $\pm \mathrm{SE}$ ) was significantly higher $(P<0.02)$ than the basal level and occurred 35 minutes after ingestion of the meal (fig 1). This represented an increase in pressure of $31 \pm 8 \%$ from

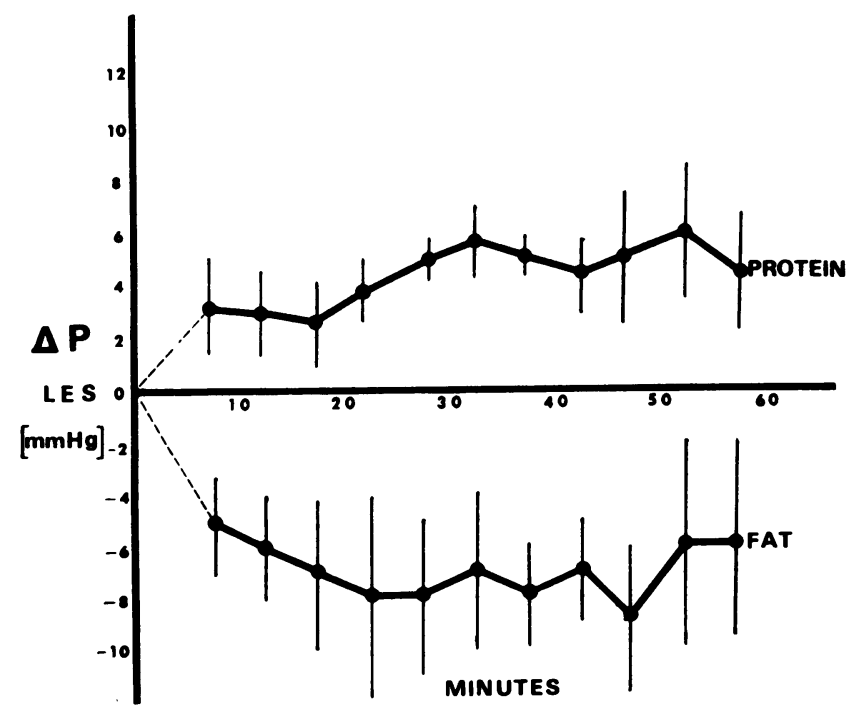

Fig 1 (Upper line) Mean changes in lower oesophageal sphincter pressure from the basal level in $\mathrm{mm} \mathrm{Hg}$ in five subjects after ingestion of a protein meal. (On this and subsequent figures the vertical brackets indicate $\pm 1 S E$ of the mean. The broken line represents the time of meal ingestion.) Lower line Mean change in lower oesophageal sphincter pressure from the basal level in five subjects after ingestion of a fat meal. 
a mean basal level of $18.6 \pm 2.5 \mathrm{~mm} \mathrm{Hg}$. By contrast, the fat meal produced decreases in lower oesophageal sphincter pressure in all five subjects (fig 1). The maximum decrease was $9.0 \pm 2.7 \mathrm{~mm}$ $\mathrm{Hg}$, which was significantly less $(\mathrm{P}<0.05)$ than the mean basal pressure of $22.4 \pm 4.4 \mathrm{~mm} \mathrm{Hg}$ and represented a $40 \cdot 2 \pm 12 \cdot 1 \%$ decrease in pressure.

The combined protein and fat meal resulted in decreased sphincter pressure in all five subjects. The maximal fall in pressure was $3 \cdot 0 \pm 2 \cdot 1 \mathrm{~mm} \mathrm{Hg}(19 \pm$ $13 \%$ decrease from a basal level of $16 \pm 2 \cdot 2 \mathrm{~mm} \mathrm{Hg}$ ) after ingestion of the meal (fig 2). Pressure levels after the combined meal were significantly lower $(P<0.01)$ than those obtained after protein alone.

PENTAGASTRIN AND FAT

Following subcutaneous injection of $3.0 \mu \mathrm{g} / \mathrm{kg}$ of pentagastrin to fasting subjects, a rise in sphincter pressure of $20.6 \pm 3.2 \mathrm{~mm} \mathrm{Hg}$ from a basal level of $15.0 \pm 2.3 \mathrm{~mm} \mathrm{Hg}$ occurred seven minutes after the injection (fig. 3). On a subsequent day ingestion of the 150 calorie fat meal produced a decrease in lower oesophageal sphincter pressure of $5.8 \pm 1.5$ $\mathrm{mm} \mathrm{Hg}$ by 15 minutes from a basal level of $15.0 \pm$
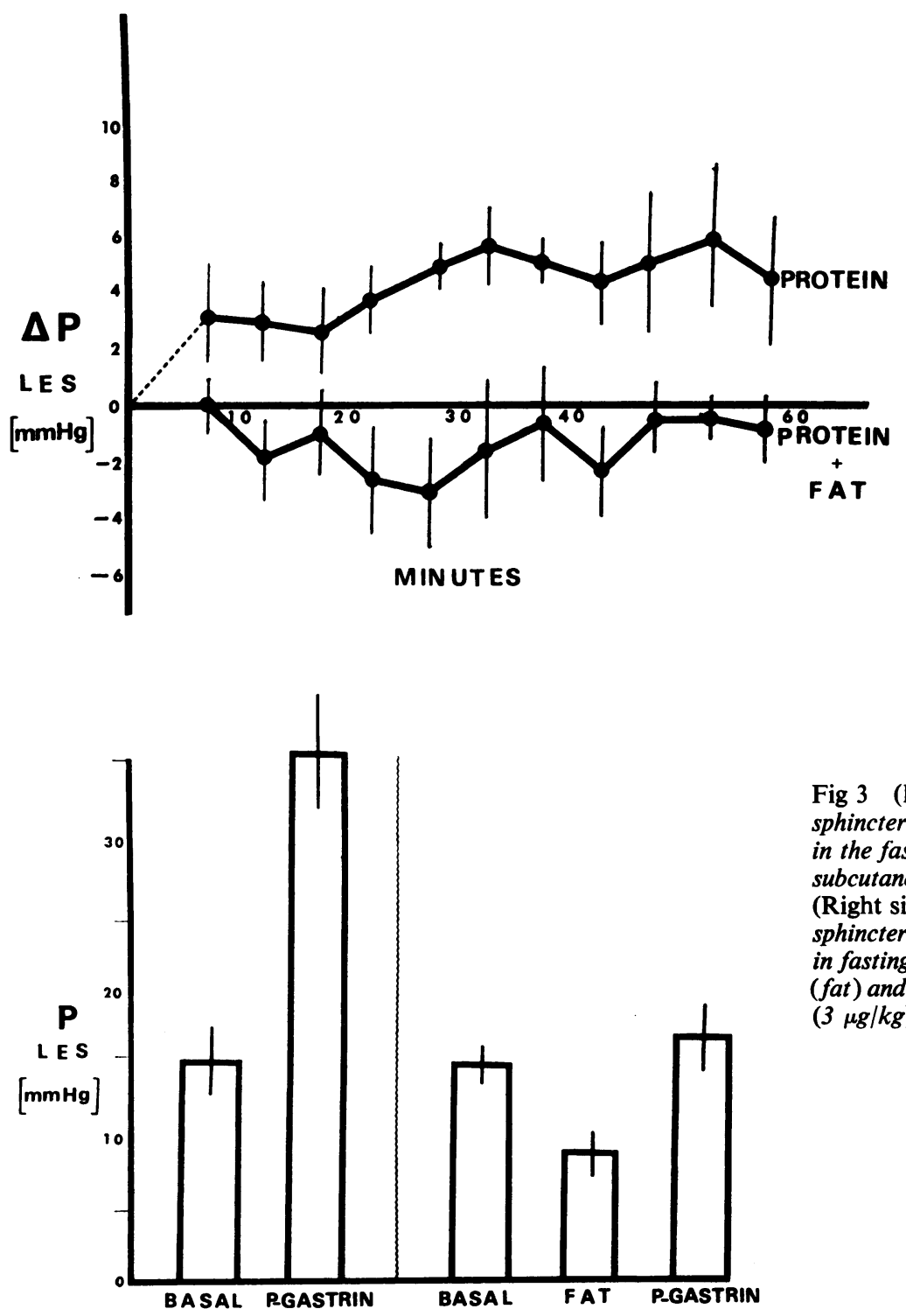

Fig 2 (Upper line) Mean change in lower oesophageal sphincter pressure from the basal level in five subjects after ingestion of a protein meal.

(Lower line) Mean change in lower oesophageal sphincter pressure in five subjects after ingestion of a combined protein/fat meal.
Fig 3 (Left side) Mean lower oesophageal sphincter pressure ( $\mathrm{mm} \mathrm{Hg}$ ) in five subjects in the fasting state (basal) and after subcutaneous pentagastrin (3 $\mu \mathrm{g} / \mathrm{kg}$ ). (Right side) Mean lower eosophageal sphincter pressure ( $\mathrm{mm} \mathbf{H g}$ ) in five subjects in fasting state (basal), following a fat meal (fat) and after subcutaneous pentagastrin (3 $\mu g / k g)$. 


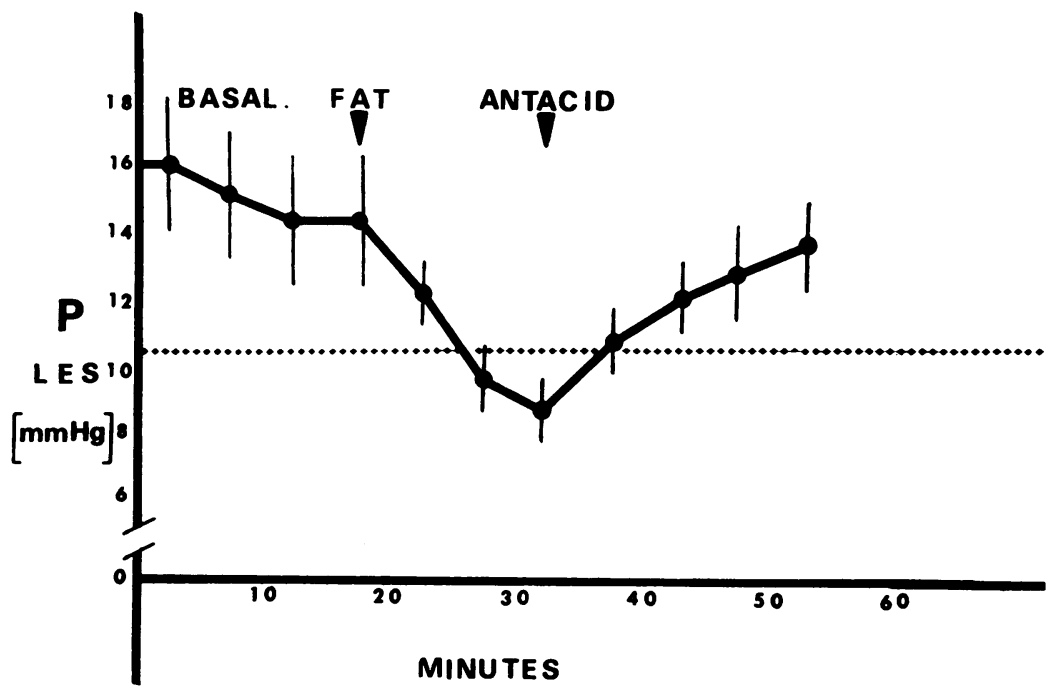

Fig. 4 Mean lower oesophageal sphincter pressure ( $\mathrm{mm} \mathrm{Hg}$ ) in five subjects during a 20-minute basal period, after ingestion of a fat meal, and after ingestion of $30 \mathrm{ml}$ of a commercial antacid. The dotted line represents the lower limit of sphincter competency.

$1.0 \mathrm{~mm} \mathrm{Hg}$. The subsequent injection of pentagastrin resulted in an increase in lower oesophageal sphincter pressure of only $8.4 \pm 1.7 \mathrm{~mm} \mathrm{Hg}$ by seven minutes (fig 3). The mean peak sphincter response to pentagastrin after fat is significantly less $(P<0.05)$ than that obtained previously when the subjects were fasting.

\section{FAT AND GASTRIC ALKALINIZATION}

Following the 150 calorie fat meal the lower eosophageal sphincter pressure decreased in all five subjects tested. From a basal level of $15.0 \pm 2.3 \mathrm{~mm}$ $\mathrm{Hg}$ sphincter pressure decreased $6.8 \pm 1.0 \mathrm{~mm} \mathrm{Hg}$ by 15 minutes to a pressure level of $8.2 \pm 1.0 \mathrm{~mm} \mathrm{Hg}$. Alkalinization with commercial antacid resulted in a subsequent increase in lower oesophageal sphincter pressure to a level of $13.4 \pm 1.6 \mathrm{~mm} \mathrm{Hg} 20$ minutes after alkalinization (fig 4).

\section{Discussion}

Although gastrin is probably the most important hormone involved in the maintenance of lower oesophageal sphincter competence (Castell and Harris, 1970; Lipshutz, Hughes, and Cohen, 1972), it is clear from recent studies on the relationship between the effects of gastrin and secretin on the sphincter that other gastrointestinal hormones may also effect sphincter pressure (Cohen and Lipshutz, 1971). The release of a variety of gastrointestinal hormones by the ingestion of food has long been known from gastric secretory studies (Saint-Hilaire et al, 1960; Debos, Bedi, Gillespie, and Gillespie, 1969; Kotrba and Code, 1969) and more recently from the radio- immune assay of serum gastrin (Hansky and Cain, 1969; Korman, Soveny, and Hansky, 1971). Changes in lower oesophageal sphincter pressure might be expected after food. Recent studies indicate that protein, acting by the release of gastrin, causes an increase in gastroesophageal sphincter pressure, that carbohydrate causes only a slight increase in sphincter pressure, and that fat causes a marked decrease in pressure, probably by the release of an enterogastrone other than secretin (Nebel and Castell, 1972).

The increase in gastroesophageal sphincter pressure following the protein meal in this study confirms our previous observation, and the decrease in sphincter pressure following the combined protein and fat meal suggests that the fat induced a reduction in the effect of gastrin. These findings are consistent with those which show (1) that the increased gastric secretion following a protein meal is mediated by release of gastrin; (2) ingestion of fat inhibits this response in secretion to a protein meal (Feng, Hou, and Lim, 1929), and (3) that ingestion of fat inhibits the effects of both endogenous and exogenous gastrin (Bibler, Harkins, and Nyhus, 1965).

The capacity of fat to reduce lower oesophageal sphincter pressure was challenged with a dose of pentagastrin $(3 \mu \mathrm{g} / \mathrm{kg})$ which has previously been shown to produce maximal increases in lower oesophageal sphincter pressures (Hollis, Levine, and Castell, 1972). When this same dose was given following ingestion of fat the response of the sphincter was attenuated to $41 \%$ of the stimulatory effect on the resting sphincter. It is known from animal studies of gastric secretion that the ingestion of fat results in an inhibition of both histamine- and gastrin-induced 
stimulation (Johnson and Grossman, 1971). This effect is believed to be mediated at least in part by cholecystokinin, which, because of its chemical similarity to gastrin, competitively inhibits the gastric secretory effect of gastrin and pentagastrin (Johnson and Grossman, 1970). Our results are consistent with a competitive inhibition of the sphincter effect of pentagastrin by an enterogastrone released by fat.

Gastric alkalinization with a variety of agents has been shown to produce substantial increases in lower oesophageal sphincter pressure, apparently through the release of endogenous gastrin from the antrum (Castell and Levine, 1971). Since commercial antacids are the mainstay of therapy of symptomatic gastrooesophageal reflux, the relative effects of ingested fat and antacid on lower oesophageal sphincter pressure were studied. In our normal subjects mean sphincter pressure after fat decreased to a level found in patients with gastrooesophageal reflux (Winans and Harris, 1967), that is, less than 10-11 $\mathrm{mm} \mathrm{Hg}$ above intragastric fundic pressure. After antacids the pressure returned to a normal range. These results indicate that the fall in sphincter pressure after a fat meal can be reduced by subsequent antacid ingestion.

These previously unknown effects of a mixed protein-fat meal provide an attractive explanation for the frequently observed relationship between ingestion of food and symptomatic oesophageal reflux. They also suggest that treatment with antacids, as well as being empirically useful, is physiologically sound.

The opinions expressed here are those of the authors and cannot be construed as reflecting the views of the Navy Department or of the Naval Service at large.

\section{References}

Bibler, D. D., Jr., Harkins, H. N., and Nyhus, L. M. (1965). Inhibition of exogenous gastrin-stimulated secretion by fat in the duodenum. Rev. Surg. (Philad.), 22, 455-456.

Castell, D. O., and Harris, L. D. (1970). Hormonal control of gastroesophageal-sphincter strength. New Engl.J. Med., 282, 886-889.

Castell, D. O., and Levine, S. M. (1971). Lower esophageal sphincter response to gastric alkalinization. Ann. intern. Med., 74, 223-227.

Cohen, S., and Lipshutz, W. (1971). Hormonal regulation of human lower esophageal sphincter competence: interaction of gastrin and secretin. J. clin. Invest, 50, 449-454.

Debas, H. T., Bedi, B. S., Gillespie, G., and Gillespie, I. E. (1969). Mechanism by which fat in the upper small intestine inhibits gastric acid. Gastroenterology, 56, 483-487.

Feng, T. P., Hou, H. C., and Lim, R. K. S. (1929). On the mechanism of the inhibition of gastric secretion by fat. Clin. J. Physiol., 3, 371-380.

Hansky, J., and Cain, M. D. (1969). Radioimmunoassay of gastrin in human serum. Lancet, 2, 1388-1390.

Hollis, J. B., Levine, S. M., and Castell, D. O. (1972). Differential sensitivity of the human esophagus to pentagastrin. Amer. J. Physiol., 222, 870-874.

Johnson, L. R, and Grossman, M. I. (1970). Analysis of inhibition of acid secretion by cholecystokinin in dogs. Amer. J. Physiol., 218, 550-554.

Johnson, L. R., and Grossman, M. I. (1971). Intestinal hormones as inhibitors of gastric secretion. Gastroenterology, 60, 120-144.

Korman, M. G., Soveny, C., and Hansky, J. (1971). Effect of food on serum gastrin evaluated by radioimmunoassay. Gut, 12, 619. 624.

Kotrba, C., and Code, C. F. (1969). Gastric acid secretory responses to some purified foods and to additions of sucrose or olive oil. Amer. J. dig. Dis., 14, 1-8.

Lipshutz, W., Hughes, W., and Cohen, S. (1972). The genesis of lower esophageal sphincter pressure: Its identification through the use of gastrin antiserum. J. clin. Invest., 51, 522-529.

Nebel, O. T., and Castell, D. O. (1972). Lower esophageal sphincter pressure changes after food ingestion. Gastroenterology, 63, 778-783.

Saint-Hilaire, S., Lavers, M. K., Kennedy, J., and Code, C. F. (1960). Gastric acid secretory value of different foods. Gastroenterology, 39, 1-11.

Winans, C. S., and Harris, L. D. (1967). Quantitation of lower esophageal sphincter competence. Gastroenterology, 52, 773 778. 